\title{
EPIDEMIOLOGICAL STUDY IN SYMPTOMATIC PATIENTS OF VAGINAL DISCHARGE IN INDUSTRIAL POPULATION
}

\author{
Ankit Kapoor1, Bhwana Kapoor ${ }^{2}$, Samir Shah 3 , Nitin Vora 4 \\ ${ }^{1}$ Assistant Professor, Dept. of Skin \& V. D, Mayo Institute of Medical Sciences, Safedabad, Barabanki, Uttar Pradesh. \\ ${ }^{2}$ Assistant Professor, Dept. of Skin \& V. D, Mayo Institute of Medical Sciences, Safedabad, Barabanki, Uttar Pradesh. \\ ${ }^{3}$ Deputy Director ESIS, Gujarat Former Professor \& PG Guide, Dept. of Skin \& V.D, General Hospital Bapunagar, E.S.I. Scheme, C/o. B. J. \\ Medical College, Civil Hospital, Ahmedabad, Gujarat. \\ ${ }^{4}$ Dean, GMERS Medical College \& Hospital, Sola, Ahmedabad, Former HOD Professor \& PG Guide, Dept. of Skin \& V.D, General Hospital \\ Bapunagar, E.S.I. Scheme, C/o. B. J. Medical College, Civil Hospital, Ahmedabad, Gujarat.
}

\section{ABSTRACT}

\section{BACKGROUND}

Vaginal discharge (VD) is one of the most common clinical complaints among women of reproductive age in many parts of the world.1/2 It may present with varied symptoms $\&$ and has many etiologies.

\author{
AIMS \\ Main objective of the study was to know the epidemiological factors associated with the symptomatic patients of vaginal \\ discharge

\section{SETTING AND DESIGN} \\ Present study was conducted in industrial population. Present study comprised of 150 women attending the STD clinic with chief \\ complains of vaginal discharge.
}

\section{METHODS AND MATERIAL}

History regarding the socio economic status, education, working or non working, contraceptive methods used and hygiene was specifically noted. History of all patients, including the H/o present and past illness, treatment taken, obstetric \& menstrual history, history of contraceptive method used, personal history and hygiene, history regarding sexual behaviour, H/o spouse/partner having genital complaints/discharge were also taken and recorded. After making the clinical diagnosis, appropriate tests for diagnosing candidiasis, trichomoniasis, gonorrhoea, chlamydia and bacterial vaginosis were done.

\section{RESULTS}

Youngest patient in present study was 19 years old and was diagnosed as having Trichomoniasis. Eldest patient was of 52 years, having Candidiasis. In present study $62.66 \%$ of patients were having income below Rs.3500/month. No divorcee or widows were found in the study. Only five patients were working rest were house wives. In present study $62.66 \%$ of patients were having income below Rs.3500/month. Only five patients were working rest were house wives. In the present study, 12 females were pregnant.

\section{CONCLUSIONS}

Most of these women are young, indigent and faced with social challenges that often pose more of an immediate threat to their well being. ${ }^{24} \mathrm{~A}$ Good number of cases do not seek treatment either due to the fear of guilt or because they are a symptomatic. ${ }^{12}$

\section{KEYWORDS}

Vaginal Discharge, Symptomatic, Socioeconomic Status.

HOW TO CITE THIS ARTICLE: Kapoor A, Kapoor B, Shah S, et al. Epidemiological study in symptomatic patients of vaginal discharge in industrial population. J Evolution Med Dent Sci 2016;5(1):92-95, DOI: 10.14260/jemds/2016/21

\section{INTRODUCTION}

Vaginal discharge (VD) is one of the most common clinical complaints among women of reproductive age in many parts of the world. ${ }^{1,2}$ It may present with varied symptoms \& and has many etiologies. VD may be observed in several physiological and pathological conditions, it may be either because of local conditions or systemic causes or both.

Financial or Other, Competing Interest: None

Submission 16-12-2015, Peer Review 17-12-2015,

Acceptance 29-12-2015, Published 04-01-2016.

Corresponding Author:

Dr. Ankit Kapoor,

4/491, Vivek Khand,

Gomti Nagar,

Lucknow-226010.

E-mail:drankitkapoor@gmail.com

DOI:10.14260/jemds/2016/21
Identifying its source can be challenging, because a large number of pathogens cause vaginal and cervical infection, and several infections may co-exist. ${ }^{3}$

Vaginal Discharge (Vagina; in Latin means sheath. ${ }^{4}$ and discharge means flowing away of secretions or excretion) is one of the commonest complaint in women attending the STD clinics, gynecology clinics, general practitioners and reproductive health clinics. For ages the term Vaginal Discharge (VD) has been used synonymously with leucorrhoea-defined as whitish discharge, which is not associated with menstruation. ${ }^{5}$

Vaginal discharge is a common clinical problem in women with varied symptoms and many etiologies. VD may be observed in several physiological and pathological conditions, it may be either because of local conditions or systemic causes or both. Identifying its source can be challenging, because a large number of pathogens cause vaginal and cervical infection 
and several infections may co-exist. ${ }^{2}$ Patient history and physical examination findings may suggest a diagnosis. ${ }^{6}$

Present study was conducted in industrial population. Main objective of the study was to know the epidemiological factors associated with the symptomatic patients of vaginal discharge. Study also aims to find the contributory or precipitating factor for causing vaginal discharge if any in this particular group.

Reason for choosing this particular group is because general awareness about the STDs, condom usage, maintaining hygiene and tendency to seek quality STD health care is generally lacking, in this group, especially in women.

\section{METHOD}

Present study comprised of 150 women attending the STD clinic with chief complains of vaginal discharge. Women who were in menstrual phase or had received any treatment for discharge in preceding six weeks were not included in present study. Unmarried females and patients having discharge due to the gynaecological conditions such as fistulae, tumours, radiation effects, post-operative were also not included.

History regarding the socio economic status, education, working or non-working, contraceptive methods used and hygiene was specifically noted. History of all patients, including the $\mathrm{H} / \mathrm{o}$ present and past illness, treatment taken, obstetric \& menstrual history, history of contraceptive method used, personal history and hygiene, history regarding sexual behaviour, H/o spouse/partner having genital complaints/discharge were also taken and recorded. After making the clinical diagnosis, appropriate tests for diagnosing candidiasis, trichomoniasis, gonorrhoea, chlamydia and bacterial vaginosis were done.

Local examination to see for any discharge, oedema, ulceration, erosion, growth or any other lesions and hygiene was done. Presence of any pain, tenderness or restricted cervical movement was also looked for. Warm water was used to provide sufficient lubrication for the speculum insertion in each patient.

The amount, source, color, consistency and odor of the vaginal discharge were noted. Cervical mobility was also noted. Swabs were subjected to following/various tests and slide preparations. Wet film (Amine/Whiff test) and 10\% KOH preparation examined immediately under microscope. Amsel's criterion was used for diagnosing Bacterial Vaginosis. Gram stain, Tzank smear and cultures were also done as and when indicated.

\section{RESULTS}

Total of 150 patients attending the STD clinic were observed. The following observations were found.

\section{Age Distribution}

\begin{tabular}{|c|c|c|c|}
\hline $\begin{array}{c}\text { Sl. } \\
\text { No. }\end{array}$ & Age Group & $\begin{array}{c}\text { No. of } \\
\text { Patients }\end{array}$ & $\begin{array}{c}\text { Percentage } \\
(\mathbf{\% )}\end{array}$ \\
\hline 1. & $15-25$ & 14 & 9.33 \\
\hline 2. & $26-35$ & 64 & 42.66 \\
\hline 3. & $36-45$ & 56 & 37.33 \\
\hline 4. & $46-55$ & 16 & 10.66 \\
\hline \multicolumn{4}{|c|}{ Table 1 } \\
\hline
\end{tabular}

Youngest patient in present study was 19 years old and was diagnosed as having Trichomoniasis. Eldest patient was of 52 years, having Candidiasis. Maximum number of patients belonged to the $26-35$ years age group (42.66\%) followed by $36-45$ (37.33\%) years age group.

\section{Educational Status}

\begin{tabular}{|c|c|c|c|}
\hline Sl. No. & Educational Status & $\begin{array}{c}\text { No. of } \\
\text { Patients }\end{array}$ & $\begin{array}{c}\text { Percentage } \\
\text { (\%) }\end{array}$ \\
\hline 1. & Illiterate & 33 & 22.00 \\
\hline 2. & Primary & 45 & 30.00 \\
\hline 3. & ${ }^{*}$ SSC & 55 & 36.66 \\
\hline 4. & ${ }^{N} \mathrm{HSC}$ & 15 & 10.00 \\
\hline 5. & Graduate & 2 & 1.33 \\
\hline \multicolumn{3}{|c|}{ Table 2 } \\
\hline
\end{tabular}

$\left({ }^{*} \mathrm{SSC}=\right.$ Secondary school certificate; ${ }^{\wedge} \mathrm{HSC}=$ Higher secondary certificate).

Table 2 shows that $52 \%$ patients were having primary level or below primary level education. $1.33 \%$ of patients had attended the college.

\section{Socioeconomic Status}

\begin{tabular}{|c|c|c|c|}
\hline Sl. No. & Economic Status & $\begin{array}{c}\text { No. of } \\
\text { Patients }\end{array}$ & $\begin{array}{c}\text { Percentage } \\
\text { (\%) }\end{array}$ \\
\hline 1. & $<1500$ & 15 & 10.00 \\
\hline 2. & $1500-3500$ & 79 & 52.66 \\
\hline 4. & $3501-6500$ & 51 & 34.00 \\
\hline 5. & $>6501$ & 5 & 03.33 \\
\hline \multicolumn{4}{|c|}{ Table 3 } \\
\hline
\end{tabular}

In present study $62.66 \%$ of patients were having income below Rs.3500/month. No divorcee or widows were found in the study. Only five patients were working rest were house wives.

\section{H/O Contraception}

\begin{tabular}{|c|c|c|c|}
\hline $\begin{array}{c}\text { Sl. } \\
\text { No. }\end{array}$ & $\begin{array}{c}\text { Contraceptive } \\
\text { Method }\end{array}$ & $\begin{array}{c}\text { No. of } \\
\text { patients }\end{array}$ & $\begin{array}{c}\text { Percentage } \\
\text { (\%) }\end{array}$ \\
\hline 1. & Tubal Ligation & 70 & 46.66 \\
\hline 2. & $\begin{array}{c}\text { Condom use by } \\
\text { partner }\end{array}$ & 32 & 21.33 \\
\hline 3. & Copper-T & 10 & 6.66 \\
\hline 4. & 0.C.P. & 2 & 1.33 \\
\hline 5. & No method used & 36 & 24.00 \\
\hline \multicolumn{3}{|c|}{ Table 4 } \\
\hline
\end{tabular}

Maximum patients (46.66\%) had undergone tubal ligation. Condom was being used by $21.33 \%$ of patients, IUCD by $6.66 \%$ patients and O.C.P. by $1.33 \%$ patients only. Amongst 10 patients of IUCD $4(40 \%)$ patients were having Bacterial Vaginosis $(n=63)$. In rest of them either non-specific vaginitis was found or no organism was cultured.

H/O Sexual Exposure: Unmarried females were not included in the study. None of the patients in this study gave history of extra marital sexual exposure.

In the present study 12 females amongst the 150 were pregnant. Only 5 patients were working rest were house wives. Pregnant females $(n=12)$ who had complained of 
vaginal discharge showed maximum incidence of Candidiasis (66.66\%), followed by bacterial vaginosis (16.66\%) as seen in Table no. 5. Total 4 patients of diabetes mellitus were seen in present study and all were having VVC. One patient aged 32 yrs. was HIV positive who had both VVC and TV. Another patient had history of recurrent abortions, was TORCH positive (IgG and IgM for HSV1 and 2) also had TV.

Hygiene status of the patients varied from good to poor. Maximum patients of VVC had good hygiene (83.33\%). TV had most patients in poor hygiene $(80.00 \%)$ category.

Maximum no. patients in present study were having bacterial vaginosis (42\%) followed by candidiasis $(24 \%)$ and Trichomoniasis (10\%).

\section{Prevalence in Pregnant Females vs Non-Pregnant Females}

\begin{tabular}{|c|c|c|c|c|c|}
\hline \multirow{2}{*}{ No. } & \multirow{2}{*}{ Disorder } & \multicolumn{2}{|c|}{ Prégnant (n=12) } & \multicolumn{2}{c|}{$\begin{array}{c}\text { Non Pregnant } \\
(\mathbf{n}=138)\end{array}$} \\
\cline { 3 - 6 } & & No. & Percentage & No. & Percentage \\
\hline 1. & $\begin{array}{c}\text { Vaginal } \\
\text { Candid. }\end{array}$ & 8 & 66.66 & 28 & 20.28 \\
\hline 2. & Bact. vaginosis & 2 & 16.66 & 61 & 44.20 \\
\hline 3. & Trichomoniais & 1 & 8.33 & 14 & 10.14 \\
\hline 4. & $\begin{array}{c}\text { Mixed } \\
\text { Infection }\end{array}$ & 1 & 8.33 & 6 & 4.34 \\
\hline 5. & $\begin{array}{c}\text { Gonocicocal } \\
\text { cervicitis }\end{array}$ & - & - & 12 & 8.69 \\
\hline 6. & $\begin{array}{c}\text { Chlamydial } \\
\text { cervicitis }\end{array}$ & - & - & 5 & 3.62 \\
\hline & TOTAL & $\mathbf{1 2}$ & $\mathbf{1 0 0}$ & $\mathbf{1 3 8}$ & $\mathbf{1 0 0}$ \\
\hline \multicolumn{7}{|c|}{ Table 5 } \\
\hline
\end{tabular}

\section{DISCUSSION}

Present study of 150 patient unfolded several multifaceted factors which may be directly or indirectly involved in acquiring the disorders.

Present study was conducted in industrial population. In this group factors like low education status, customs, low status of female in society, etc. play important role in their health status. General awareness about the STDs, condom usage, maintaining hygiene and tendency to seek quality STD health care is generally lacking, especially in women.

Maximum number of patients belonged to the 26-35 years age group (42.66\%) followed by $36-45$ (37.33\%) years age group which is in accordance with $\mathrm{V}$ Gupta. ${ }^{7}$ et al. where the commonest age group affected was 26-35 yrs age group (36\%) followed by $36-45$ yrs (27.3\%). $22 \%$ of patients were illiterate and only $1.33 \%$ of patients had attended the college.

This is in comparison to study of Datey S et al. ${ }^{8}$ where $18.2 \%$ patients were illiterate. This again supports the high impact of female education on sexual and reproductive health. ${ }^{9}$ Among women using any form of contraception, IUCD users were affected with BV the most. In present study also amongst 10 patients of IUCD, 4 (40\%) patients were associated with bacterial vaginosis. All OCP users in present study were suffering from Candidiasis.

None of the patients in this study gave history of extra marital sexual exposure. Cultural norms in India are conservative and women are not expected to have extramarital relations. ${ }^{8}$ The result of our study corroborate that many women adhere to these cultural values and adopt a life style to follow these norms. It might be also because of social taboos involved and also because of fear of marital disharmony and disruption of personal family life and future of kids.
Pruritus in present study was the commonest complaint was seen in $51.33 \%$ of the patients is comparable with studies of KJPS Puri et al. ${ }^{6}$ (49\%) and V. Gupta. ${ }^{7}$ et al. (43.9\%). Lack of cleanliness, acidic discharge and diabetes could be the cause for pruritus in VD. ${ }^{10}$

Following factors like Increasing age. ${ }^{11} \mathrm{~h} / \mathrm{o}$ of recent intercourse in last $48 \mathrm{hrs} .{ }^{11}$ lower socioeconomic status. ${ }^{11}$ sexually active age group during child bearing age. ${ }^{2}$ previous pregnancy, OCPs, previous Trichomoniasis infection. ${ }^{11}$ use of Intrauterine devices. ${ }^{11}$ and co-existent infection with $\mathrm{N}$. Gonorrhoea. ${ }^{11}$ had positive correlation with the high prevalence of BV.

In present study patients of BV had foul smelling (77.77\%), white $(90.47 \%)$, homogenous $(84.12 \%)$, moderate (39.68\%) to severe (39.68\%) discharge, uniformly coating the vaginal walls. Whiff test was positive in $47.6 \%$ and in microscopic result, CLUE cells were seen in the $82.5 \%$ of patients.

Trichomoniasis was seen in $10 \%$ of patients in present study, which is in accordance with that V. Gupta. ${ }^{7}$ (7.9\%), V. Acharya et al. ${ }^{12}(11.32 \%)$, Ries AJ. ${ }^{13}(10 \%)$ and Levett PN. ${ }^{14}$ (8.6\%). The poor local hygienic condition, colonization of the Candida and anaemia helps in colonization and multiplication of T. Vaginalis. ${ }^{15}$ Incidence of trichomoniasis has decreased in recent years. Natarajan et al. ${ }^{16}$ observed a changing profile of vaginal Trichomoniasis by diminishing trend of acute symptoms and increasing trend of asymptomatic status. ${ }^{6}$

It was observed that increasingly wide use drugs like metronidazole for gynaecological and non-gynaecological indications should be contributing to this changing profile of trichomonial infection. ${ }^{6}$ from cervical smears. Mixed Infection was seen in $4.66 \%$ of patients in present study. Non-specific vaginitis was seen in only $4(2.66 \%)$ patients in present study.

Incidences of most of the disorders vary considerably. They differ from place to place, time to time, rural to urban from one society to another and age group of the patient included in the study. Following factors like Socio economic status, Diabetes Mellitus, sexual activity, personal hygiene, poor utilization of health services by young married women, methods of contraception used, co-existent infection also result in varied incidences of above disorders.

Bacterial vaginosis was more common in Non pregnant women $(44.20 \%$ vs. $16.66 \%)$, whereas vulvovaginal candidiasis is more common in the pregnant females $(66.66 \%$ vs. $20.28 \%$ ). Similar was also observed by Levett PN.14 who found that Bacterial Vaginosis was more common in nonpregnant women (33\% vs. $23 \%$ ) and candida albicans was more common in the pregnant women (49\% vs. 39\%). Findings of current study can also be compared with KJPS P. et $\mathrm{al},{ }^{5}$ where candida albicans was more common in the pregnant women (61.53\% vs. $26.43 \%$ ) and bacterial vaginosis was more common in non-pregnant women ( $47.12 \%$ vs. $30.76 \%)$.

During pregnancy, the vagina shows increased susceptibility by Candida species resulting in both higher rate of vaginal colonization and a higher rate of symptomatic vaginitis. ${ }^{17}$ It is generally thought that high levels of hormones by providing higher glycogen content in the vaginal tissue, provide an excellent carbon source for Candida organisms. It is also said that oestrogen enhances the adherence of the yeast cells to the vaginal mucosa. 


\section{CONCLUSION}

Most of these women are young, indigent and faced with social challenges that often pose more of an immediate threat to their wellbeing. A good number of cases do not seek treatment either due to the fear of guilt or because they are a symptomatic. ${ }^{12}$

Because of their inherent biological vulnerability for RTI/STI all females must be screened periodically for the evidence of genital tract involvement so that they can promptly and effectively treated. Prevalence of these disorders is influenced by several multifaceted factors which may be directly or indirectly involved in acquiring the disorders.

In time management of vaginal discharge not only prevents spread of disease, minimizes/prevents complications (Like PID, Female Infertility). ${ }^{12}$ brings down the high expenses involved in treating them and possibly also the HIV transmission. ${ }^{18}$ Because of the relatively trivial nature of VD, cost and time factor, lack of specialized instruments and skilled man power, treatment may be initiated based on clinical finding alone at times. However the common aetiological agents of vaginal discharge respond to specific therapies and their symptoms are sufficiently similar to render clinical diagnosis difficult. Therefore, laboratory investigations are appropriate.

\section{REFERENCES}

1. Eschenbach DA, Hillier S, Critchlow C, Stevens C, De Rousen T, Holmes KK. Diagnosis and clinical manifestations of BV. Am J Obstet Gynaecol 1988;158:819-828.

2. Rao PS, Devi S, Shriyan A, et al. Diagnosis of bacterial vaginosis in a rural setup: Department of Microbiology, Kasturba Medical College, Manipal. Comparison of clinical algorithm, smear scoring and culture by semi-quantitative technique. Indian J Med Microbiol 2004;22:47-50.

3. Fox KK, Behets FM. Vaginal discharge. How to pinpoint the cause. Postgraduate Medicine 1995;98:87-90, 93- 96, 101. In IJDVL Volume 69; 2003: Issue 2, pg122-125.

4. Tabers Cyclopedic med dictionary 18th edition: Jaypee Publishers, Printed at Delhi: Pg 2054.

5. AJ Kanwar; Clinical Approach to Vaginal/Urethral Discharge: In Sexually Transmitted Disease and AIDS, V.K. Sharma: Printed at New Delhi: 2003, Viva Publishers: 1st edition; Chpt 43, Pg 463-470.

6. KJPS Puri, Anita M, Kiran B: Incidence of various causes of vaginal discharge amongst sexually active females in age group 20-40 yrs: IJDVL 2003; VOL 69, Issue 2, pg 122-125.
7. Gupta V, Biswaroop C, Devender P, et al. Clinical spectrum and microbial etiology of reproductive tract infections in rural women in the hills of North India; In J of Obs \& Gyn of India Vol 52, no. 1: Jan/Feb 2002, pg 130-134.

8. Datey S, Bedi N, Gaur LN, et al.: STIs among antenatal women in five tertiary hospitals in India. (An ICMR Task Force Study): J Obstet Gynecol India Vol. 53, No. 1: January/February 2003, pg 53-58.

9. Chandhiok $\mathrm{N}$ et al.: Prevalence of Chlamydia Trachomatis in women attending different tertiary hospitals (An ICMR Task Force Study): J Obstet Gynecol India Vol. 53, No. 5: September/October 2003, pg 463-467.

10. The practice of gynecology by John Wesley Bovée in English; Published by Philadelphia and New York, Lea brothers \& co. 1906; Digitized 16 march 2006. OCLC: 14806325: Link to this Page: http://worldcat.org/oclc/14806325.

11. Bhalla P, Kaushika A. Epidemiological and microbiological correlates of bacterial vaginosis. Indian J Dermatol Venereol Leprol 1994;60:8-14.

12. Acharya $V$, Mathur D, Jain P, et al. Sexually transmitted diseases in gynaecological practise: J of Obs \& Gyn, Vol. XXXVIII, June 1990-No.3: Pg 341-343.

13. Reis AJ. Treatment of vaginal infections: candidiasis, bacterial vaginosis and trichomoniasis. J Am Pharm Asssoc. (Wash) 1997; NS 37:Pg 563-569: IJDVL 2003; VOL 69, Issue 2, pg 122-125.

14. Levtt PN: Aetilogy of vaginal infections in pregnant and non-pregnant women in Barbados. West Indian Med J: 1995;44:96-98: In IJDVL 2003; VOL 69, Issue 2, pg 122125.

15. Agrawal BM, Agrawal S, Singh PK, et al. Trichomonas vaginalis-An indicator for other sexually transmitted infecting agents. Indian J Dermatol Venereol Leprol 2000;66:241-243.

16. Natarajan S, Kumar P. Changing clinical profile of vaginal trichomoniasis. Obstet Gynaecol 1990; D 40: pg 809-811. In IJDVL 2003; VOL 69, Issue 2, pg 122-125.

17. KJPS Puri, Anita M, Kiran B: Evaluation of the causes of the vaginal discharge in relation to pregnancy status: IJDVL 2003; VOL 69, Issue 2, pg 129-130.

18. Khaira Harikaran Kaur, Puri KJPS, Anita M, Kiran B: Prevalence of bacterial vaginosis in sexually active females: Obstet Gynecol India Vol. 53, No. 2: March/April 2003, pg 178-180. 